\title{
The effect of Saccharomyces cerevisiae and Aspergillus oryzae on the digestion of the cell wall fraction of a mixed diet in defaunated and refaunated sheep rumen
}

\author{
Jean-Pierre Jouanya*, Frédérique Mathieu ${ }^{\mathrm{a}, \mathrm{b}, \mathrm{c}}$, Jean Senaud ${ }^{\mathrm{b}}$, \\ Jacques Bohatier ${ }^{\mathrm{b}}$, Gérard Bertin ${ }^{\mathrm{c}}$, Mariette Mercier ${ }^{\mathrm{d}}$ \\ a Inra, SRNH, Centre de Clermont-Theix, 63122 Saint-Genès-Champanelle, France \\ b Université Blaise-Pascal, URA CNRS 1944, Les Cézeaux, 63177 Aubière cedex, France \\ c Santel, 22-24, rue du Président-Wilson, 92300 Levallois-Perret, France \\ ${ }^{d}$ Laboratoire de biostatistiques, Université de Franche-Comté, 4, place Saint-Jacques, \\ 25030 Besançon, France
}

(Received 16 September 1997; accepted 20 June 1998)

\begin{abstract}
The objective of this study was to determine the effect of two probiotics, Saccharomyces cerevisiae $(\mathrm{SC})$ and Aspergillus oryzae $(\mathrm{AO})$, without their culture medium, on the digestion of plant cell wall components in sheep that had been successively defaunated and refaunated. Six sheep fitted with large rumen cannulae were used to study 1) defaunated sheep with no probiotic, 2) defaunated sheep with SC or AO, 3) refaunated sheep with no probiotic, 4) refaunated sheep with SC or AO. The apparent digestibility of the plant cell walls was not altered $(P>0.05)$ by the probiotics in defaunated sheep but was increased $(P<0.05)$ with SC $(+16 \%)$ in refaunated sheep. Simultaneously, SC stimulated the growth of the protozoal population in the rumen. As noted in most previous experiments, the positive effect of the presence of protozoa on plant cell wall digestion $(P<0.001)$ was confirmed here. The effect $(P>0.05)$ of SC or AO on in situ ADF digestion was either not significant or negative in defaunated rumens, whereas it became positive in refaunated rumen after a residence time of $12 \mathrm{~h}$. The improvement of in situ ADF digestion due to the presence of protozoa was significant $(P<0.05$ for NDF; $P<0.001$ for ADF). However, we could not determine whether this was a direct effect of protozoa or an indirect effect operating via bacteria. The limits of the nylon bag technique for evaluating the microbial activity are discussed in relation to the ability of protozoa to enter and grow in the bags, and the $\mathrm{pH}$ regulation inside the bags. The $\mathrm{pH}$ values below 5.5 noted inside the bags can significantly alter the bacterial and protozoal populations and limit the validity of the technique. SC increased $(P<0.05)$ the specific activity of CMCase and xylanase of the solid-adherent bacteria $(\mathrm{SAB})$ isolated from the rumen digesta of refaunated sheep. Stimulation of both the bacterial activity and protozoa numbers could explain the positive effect of SC on cell wall digestion in the rumen since the modelling of marker excretion in faeces showed that the ruminal mean retention time of hay measured from the model of Danhoa et al. was not modified $(P>0.05)$ by either refaunation or the
\end{abstract}

\footnotetext{
* Correspondence and reprints

E-mail: jouany@clermont.inra.fr
} 
presence of probiotics. AO increased $(P<0.05)$ the total retention time of the solid particles in the whole digestive tract and increased the ruminal liquid volume in the refaunated animals but it had no effect on the protozoa population or on the polysaccharidase activity of the $\mathrm{SAB}$, which could explain the absence of effect of $\mathrm{AO}$ on the total digestibility of plant cell walls. Both probiotics decreased the liquid turnover in defaunated rumens $(P<0.05)$ but neither had any effect $(P>0.05)$ on this parameter after refaunation. The improvement of plant cell wall degradation in the whole digestive tract is probably due to a stimulation of digestion at the rumen level as indicated by the higher activity of the $\mathrm{SAB}$ in rumen digesta and the growth of protozoa. C Inra/Elsevier, Paris

\section{rumen / Saccharomyces cerevisiae / Aspergillus oryzae / protozoa / digestion / fibre}

Résumé - Effet de Saccharomyces cerevisiae et Aspergillus oryzae sur la digestion des parois végétales d'une ration mixte dans le rumen de moutons défaunés et refaunés. Cette étude a pour objectif de déterminer l'effet de deux probiotiques, Saccharomyces cerevisiae (SC) et Aspergillus oryzae $(\mathrm{AO})$, distribués dans leur milieu de culture, sur la digestion des composés pariétaux à des moutons qui avaient été successivement défaunés puis refaunés. Six moutons porteurs de fistules permanentes du rumen ont été utilisés pendant quatre périodes expérimentales : 1) défaunés sans ajout de probiotiques, 2) défaunés et recevant $\mathrm{SC}$ ou $\mathrm{AO}, 3$ ) refaunés sans ajout de probiotiques, (4) refaunés et recevant $\mathrm{SC}$ ou $\mathrm{AO}$. La digestibilité apparente des parois végétales n'a pas été modifiée $(p>0,05)$ par l'ajout des probiotiques chez les animaux défaunés mais elle a augmenté $(p<0,05)$ en présence de SC chez les animaux refaunés. Dans le même temps, SC stimulait la population de protozoaires dans le rumen $(p>0,05)$ ainsi que l'activité spécifique de la CMCase et des xylanases produites par les bactéries adhérentes à la phase solide $(\mathrm{SAB})$ dans le rumen des animaux refaunés. AO n'a pas eu d'effet $(p>0,05)$ sur les activités enzymatiques des bactéries du rumen. L'effet positif des protozoaires sur la digestion des parois végétales dans l'ensemble a été confirmé au cours de cette expérimentation. La dégradation in situ des parois a été stimulée $(p<0,05)$ par SC ou AO chez les seuls animaux refaunés et au-delà du temps de séjour de $12 \mathrm{~h}$ des sachets dans le rumen. L'amélioration observée à la suite de l'ajout de protozoaires a été significative $(p<0,05$ pour la fraction NDF ; $p<0,001$ pour la fraction ADF). Cependant nous n'avons pas pu montrer s'il s'agissait d'un effet direct des protozoaires ou d'un effet indirect via les bactéries, ou des deux effets simultanés. La validité de la technique des sachets de nylon pour apprécier l'activité microbienne du rumen est discutée puisque nous avons montré que la population de protozoaires et la régulation du pH à l'intérieur des sachets diffèrent notablement de celles observées dans le rumen. La stimulation conjuguée de l'activité bactérienne et de la population des protozoaires peuvent expliquer l'amélioration de la digestion des parois en présence de $\mathrm{SC}$ puisque le temps de séjour des particules solides dans le rumen mesuré par le modèle de Danhoa et al. n'a pas été modifié $(p>0,05)$. Elle montre également que cette amélioration a probablement eu lieu au niveau du rumen. $\mathrm{AO}$ a provoqué une augmentation du temps de séjour total des particules dans l'ensemble du tube digestif ainsi que du volume du liquide ruminal chez les animaux refaunés mais n'a pas modifié la population des protozoaires ni les activités enzymatiques des $\mathrm{SAB}$, ce qui explique son absence d'effet sur la digestibilité globale des parois de la ration. Les deux probiotiques testés ont diminué $(p<0,05)$ la vitesse de renouvellement de liquide dans les rumens défaunés mais ils n'ont plus eu d'effet sur ce paramètre après refaunation des rumens. $\odot$ Inra/Elsevier, Paris

rumen / Saccharomyces cerevisiae / Aspergillus oryzae / protozoaire / digestion / fibre

\section{INTRODUCTION}

The intensive production of milk and meat that has developed over the last 40 years requires high-energy diets. Feed additives have been proposed to stabilize and stimulate the digestive efficiency of the ruminal ecosystem, thereby improving the nutrient supply to ruminants. Among these additives, direct-fed microbials (DFM) are viewed as biologically harmless agents, whereas chemical additives such as antibiotics are consi- 
dered risky. Also, European Union regulations restrict these to veterinary use.

Live yeasts and fungi have been extensively used as feed additives over the last decade, but their real efficiency for ruminants is still being debated [45]. Early studies $[1,42]$ indicated that DFMs increased feed intake. According to Wallace and Newbold [45], this could result from a stimulated rate of fibre degradation. However, a full search of the literature shows that no consistent effect of DFM has ever been obtained on ruminal plant cell wall degradation [35].

The objective of this study was to examine the effect of supplemental Saccharomyces cerevisiae (SC) and Aspergillus oryzae $(\mathrm{AO})$ on several parameters involved in the digestion of cell wall carbohydrates. The effects of the two probiotics were measured first in defaunated sheep and then in the same refaunated sheep, because recent work has indicated that these probiotics can change the ruminal protozoa population [3, $10,34]$. This experimental design enabled us to analyse the interactions between protozoa and probiotics for different factors controlling the digestion of plant cell walls.

\section{MATERIALS AND METHODS}

A total of nine castrated male adult Texel sheep $(72.5 \pm 5.0 \mathrm{~kg} \mathrm{LW})$ fitted with rumen cannulae and labelled from A to I were used. They were defaunated by emptying and washing the rumen according to Jouany and Senaud [21]. The experiment began following a 6-week period of adaptation to the defaunated state. Rumen contents were examined each week to verify the absence of protozoa within the rumen. Animal $B$ died at the end of the third period following necrosis of the liver aggravated by heparin injections during blood sampling. Animals $E$ and $F$ died after undergoing two closely spaced successive defaunation treatments following an accidental contamination with small entodinia at the end of the second period.
The two probiotics were a strain of Saccharomyces cerevisiae $(\mathrm{SC}$, registered as $\mathrm{CNCM} \mathrm{I-}$ 1096, Institut Pasteur, France), and a strain of Aspergillus oryzae (AO) of industrial origin. The two additives were composed of living cells $\left(20 \times 10^{9} \mathrm{cells} / \mathrm{g}\right.$ for SC; $6.5 \times 10^{8} \mathrm{spores} / \mathrm{g}$ for $\mathrm{AO}$ ) without their culture medium, and were supplied by Santel* ${ }^{*}$. They were administered through the rumen cannulae, just before the morning meal, so the exact daily dose of the two additives was known.

The experimental design has been described by Mathieu et al. [26]. During the first period, the six sheep used (A-F) were defaunated and received no probiotics. During the second period, three of them $(\mathrm{A}-\mathrm{C}$ ) received $\mathrm{SC}(50 \mathrm{mg} /$ day $)$, while the other three were fed $\mathrm{AO}$ ( $3 \mathrm{~g} /$ day). These doses are commonly used in current practice. During the third period, six sheep (A-D, G, H) were each refaunated with $200 \mathrm{~mL}$ of rumen contents containing Isotricha $\left(10^{3} / \mathrm{mL}\right)$, Epidinium $\left(10^{4} / \mathrm{mL}\right)$, Eudiplodinium $\left(10^{4} / \mathrm{mL}\right)$ and Entodinium $\left(10^{5} / \mathrm{mL}\right)$. Measurements started 4 weeks after the ciliate population had stabilized. During the fourth period, three sheep (A, I, C) received SC (50 mg/day); three others (D, G, H) were fed $\mathrm{AO}$ ( $3 \mathrm{~g} /$ day). Periods 2 and 4 began 2 weeks after the addition of probiotics although the recommended level of live cells was reached in the rumen digesta on the day following the first administration (Chaucheyras, pers. comm.).

The sheep were housed in individual stalls in a building specifically designed to avoid all direct contact between animals and so prevent contamination. They received $1350 \mathrm{~g} /$ day of a mixed diet (table $I$ ) fed twice daily in equal meals, at 0900 and 1600 hours. Because of the high proportion of barley, the sheep were adapted to the diet gradually for 1 month before measurements began. The measurements were carried out concurrently on the six sheep using the same experimental design for each period (figure 1).

Rumen fluid samples were taken for $\mathrm{pH}$ determination from the bottom of the ventral sac by suction through a tube $(1 \mathrm{~cm}$ in internal diameter) connected to a large rubber teat. Total rumen digesta were collected by completely emptying the rumen $5 \mathrm{~h}$ after the morning meal. The volume and weight of total digesta were determined. A representative sample of digesta was taken for analyses of DM, OM, NDF, ADF, ADL and determination of their ruminal pools.

* SANTEL, 22-24, rue du Président-Wilson, 92300 Levallois-Perret, France. 
Table I. Composition of the diet (g/day/animal).

\begin{tabular}{lcccr}
\hline & $\begin{array}{c}\text { Chopped } \\
\text { Timothy grass hay }\end{array}$ & $\begin{array}{c}\text { Pelleted } \\
\text { barley }\end{array}$ & $\begin{array}{c}\text { Soybean } \\
\text { meal }\end{array}$ & Total \\
\hline Fresh matter & 600.0 & 600.0 & 150.0 & 1350.0 \\
Dry matter & 539.2 & 535.5 & 133.9 & 1208.6 \\
Organic matter & 504.8 & 507.2 & 124.6 & 1136.6 \\
Crude protein $(\mathrm{N} \times 6.25)$ & 45.2 & 62.1 & 67.7 & 175.0 \\
Neutral detergent fibre & 387.8 & 82.9 & 11.2 & 481.9 \\
Acid detergent fibre & 224.3 & 30.7 & 5.8 & 260.8 \\
Acid detergent lignin & 27.4 & 4.2 & 0.3 & 31.9 \\
Starch & - & 267.8 & - & 267.8 \\
\hline
\end{tabular}

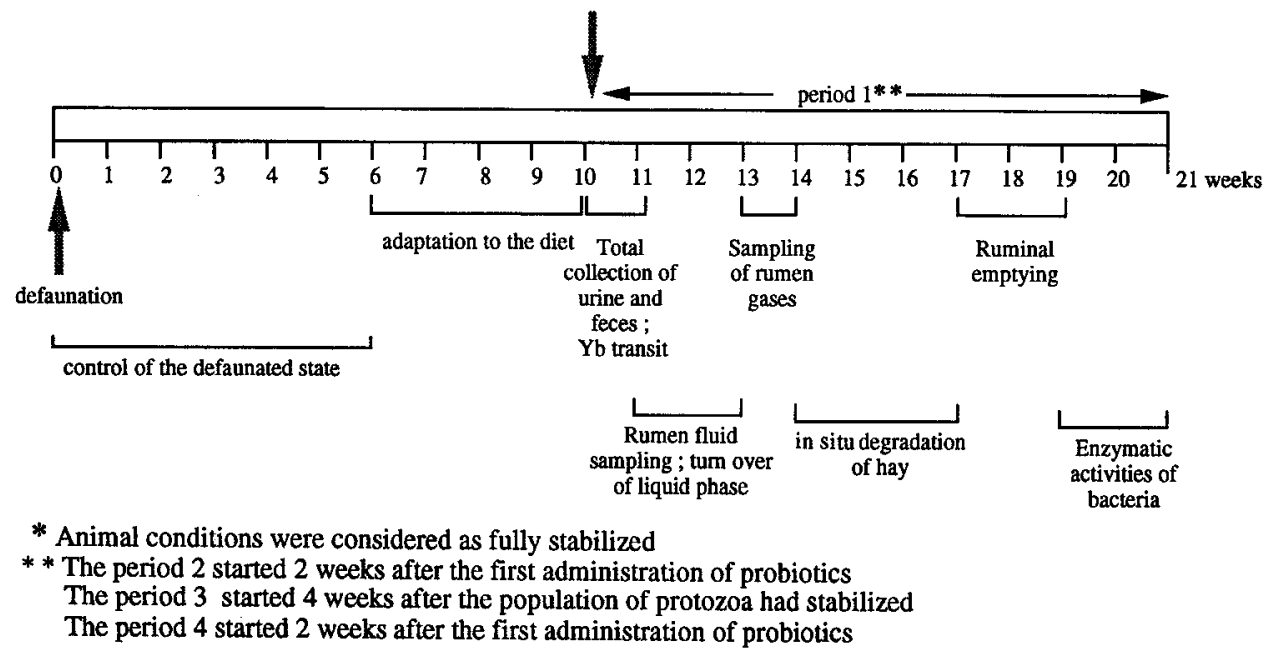

Figure 1. Experimental design.

Nylon bags ${ }^{* *}(5 \times 10 \mathrm{~cm} ; 53$ microns pore size) filled with $3 \mathrm{~g}$ (DM) of hay from the diet were incubated $(0,1,3,6,12,24,48,72 \mathrm{~h})$ using the in situ technique [27]. Hay was ground using a 4-mm screen before being introduced into the bags using the standard method developed at Inra. Kinetic studies were repeated six times per sheep. Bags removed from the rumen were gently hand-pressed before washing in cold tap water until the rinse water was clear. Because there was no plateau after a 72 -h retention time in the rumen, the kinetic data could not be fitted to the model described by $\varnothing$ rskov and Mc Donald [32]. The $\mathrm{pH}$ was determined in the liquid extracted from the bags by hand-pressure and the protozoa contained in this liquid were counted.

A single dose of $20 \mathrm{~g}$ chopped hay previously labelled with ytterbium acetate $(12.5 \mathrm{mg} \mathrm{Yb} / \mathrm{g}$ DM) according to Bernard [4] was introduced into the rumen of each animal via the cannula to evaluate the mean retention time of forage particles. Following this addition, the faeces were collected every $6 \mathrm{~h}$ for the first $24 \mathrm{~h}$, then every $3 \mathrm{~h}$ up to $60 \mathrm{~h}$, then every $6 \mathrm{~h}$ up to $96 \mathrm{~h}$, then every $12 \mathrm{~h}$ up to $168 \mathrm{~h}$. Yb was assayed by atomic absorption spectrophotometry (Perkin-Elmer Spectrophotometer 2380) as described by Sid- 
dons et al. [37]. Solutions for calibration plots were prepared with unlabelled faeces from the sheep. The mean retention times of hay particles in the whole digestive tract and its compartments were calculated from the models applied to the kinetic excretion of $\mathrm{Yb}$ in faeces and established, respectively, by Thielemans et al. [39], Danhoa et al. [9] and Faichney and Boston [11].

The turnover of the liquid phase $(k)$ in the rumen was measured from the kinetic decrease $(2,4,6,8,10,12,18,24,32 \mathrm{~h})$ of the soluble marker PEG 4000 introduced through the rumen cannulae in a single dose (100 mL of PEG solution $20 \% \mathrm{w} / \mathrm{v}$ ) just before the morning meal. The dilution rate was calculated from the equation: $\mathrm{C}_{\mathrm{t}}=\mathrm{C}_{0} \times \mathrm{e}^{(-\mathrm{kt})}$. This determination was repeated twice for each animal. PEG was assayed according to Hyden [18] using an autoanalyser.

Enzymatic activities were determined on liquid associated bacteria (LAB) and on solid adherent bacteria (SAB) only during periods 3 and 4 , when the sheep were refaunated. Liquid samples taken from the rumen just before the morning meal were filtered on two gauze layers under anaerobic conditions. Filtrates were centrifuged at $1000 \mathrm{~g}$ for $10 \mathrm{~min}$ to remove protozoa and feed particles. The supernatants were centrifuged at $20000 \mathrm{~g}$ for $20 \mathrm{~min}$ to isolate the $\mathrm{LAB}$ fraction. All centrifuging was carried out under anaerobiosis. Fifteen grams of ground hay (4-mm screen) from the diet was placed in nylon bags $(8 \times 18 \mathrm{~cm}, 95$ microns pore size), which were then left in the rumen for $24 \mathrm{~h}$. Removed bags were preserved in airtight bottles. Ten-gram wet samples from the bags were suspended in $10 \mathrm{~mL}$ of buffer MES ( $4.88 \mathrm{~g} / \mathrm{L}, \mathrm{pH} 6.5)$ in polyethylene bags and treated by a stomacher for 4 min under $\mathrm{CO}_{2}$ to detach the $\mathrm{SAB}$ fraction. The suspensions of $\mathrm{SAB}$ were then treated like the LAB. Samples were ultrasonicated for $2 \mathrm{~min}$ (four periods of $30 \mathrm{~s}$ ) to release the enzymes. Liquids were centrifuged at $3000 \mathrm{~g}$ for $20 \mathrm{~min}$ and the enzymes were analysed in the supernatants according to Williams and Withers [48]. Protein contents in the enzymatic preparations were determined according to Bradford [5].

NDF, ADF and ADL were determined by procedures outlined by Goering and Van Soest [14]. Protozoa were counted in rumen fluid and in the liquid extracted by hand-pressure from nylon bags with a Dollfuss cell as described by Jouany [19]. Dry matter (DM) was determined by oven drying at $80^{\circ} \mathrm{C}$ for $48 \mathrm{~h}$. Organic matter (OM) was measured after ashing in a muffle furnace $\left(550^{\circ} \mathrm{C}\right.$ for $\left.6 \mathrm{~h}\right)$.
The experimental design was chosen to prevent protozoal contamination of the sheep during the defaunated state. The study of the effect of probiotics was thus carried out first on defaunated sheep. We subsequently refaunated all the animals and ran the two experiments with and without probiotics. Data were processed by variance analysis using the GLM procedure of SAS [36] using the following model: $\mathrm{Y}_{\mathrm{ijk}}=\mathrm{m}$ $+A_{i}+F_{j}+F_{j}\left(P_{k}\right)+E_{i j k}$, where $Y=$ measured parameter, $\mathrm{m}=$ overall mean, $\mathrm{A}=$ animal effect, $\mathrm{F}=$ fauna effect, $\mathrm{F}_{\mathrm{j}}\left(\mathrm{P}_{\mathrm{k}}\right)$ = probiotic effect nested within fauna effect, and $\mathrm{E}=$ residual error. This model, in which the probiotic effect is 'nested within the fauna effect', was well-adapted to our experimental design, especially where there is a significant interaction between fauna and probiotics. Interactions between protozoa and probiotics were assessed with a second model: $Y_{i j k}$ $=m+A_{i}+F_{j}+P_{k}+F P_{j k}+E_{i j k}$, where $Y=$ measured parameter, $\mathrm{m}=$ overall mean, $\mathrm{A}=$ animal effect, $\mathrm{F}=$ fauna effect, $\mathrm{P}=$ probiotic effect, $\mathrm{FP}$ $=$ interaction between fauna and probiotic, and $\mathrm{E}$ $=$ residual error. The option 'repeated measures for variance analyses' was used to take into account the non-independence of the data in all the kinetic studies performed here. Because data expressed in percentages do not have a normal distribution, they were converted into their 'arcsinus' values before the statistical analysis. Means were compared in pairs using the Duncan multiple rank test. The significance threshold was set at $5 \%$.

\section{RESULTS AND DISCUSSION}

The apparent total tract digestion of the components of the diet was not modified by the addition of $\mathrm{AO}$ or SC $(P>0.05)$ in the defaunated rumens (table $I I$ ). In contrast, both DFMs stimulated the digestibility of the dietary OM $(P<0.05)$ in refaunated sheep. The hemicellulose and cellulose fractions of the diet estimated as (NDF - ADF) and (ADF - lignin), respectively, were also significantly $(P<0.05)$ better digested after the addition of SC in refaunated animals. We confirmed here that protozoa have a strong stimulating effect $(P<0.001$ for the global effect of protozoa) on the apparent total tract digestion of OM and cell wall components, mainly accounted for by a 


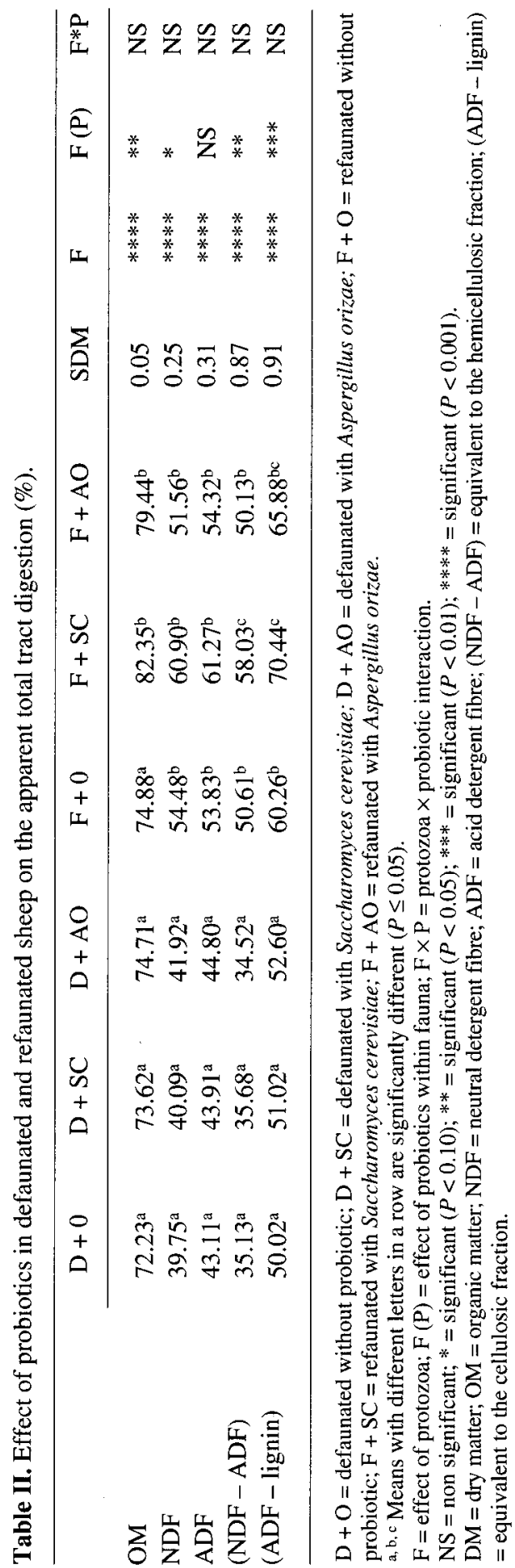

powerful stimulation of the ruminal digestion as discussed by Jouany [20].

in situ hay ADF disappearance was only significantly $(P<0.05)$ stimulated by the addition of protozoa after a 12- or 24-h incubation time in the rumen when DFMs were added or a 48-h incubation time in the nontreated animals (table III). The same effect of protozoa on NDF degradation was observed in the rumen of the DFM-treated animals while no effect or a significant decrease was noted during the first $12 \mathrm{~h}$ of the kinetics. SC and AO had either no effect or decreased $(P<0.05)$ the in situ degradation of NDF and ADF fractions in defaunated animals. This could indicate that SC operates in cell wall digestion via the rumen protozoa. Our results concerning the global positive effect of protozoa on the in situ degradation of hay cell walls shown by variance analysis $(P<0.05$ for NDF; $P<0.001$ for ADF) confirmed the abundant data currently available in the literature (see Jouany and Martin [22]).

The modifications reported in the literature on the in situ degradation of forage cell walls induced by probiotics range widely and are generally non-significant $[13,15$, $16,25,33,43,44]$. For example, Wallace et al. [46] indicated that the rate of degradation was stimulated by SC while the maximum level of degradation was not influenced. In agreement with our results, Roa et al. [35] and Miranda et al. [29] observed that the degradation rate of alfalfa hay cell walls was not influenced by SC during short incubations of bags in the rumen, whereas the amount of degraded cell walls can increase $(P<0.05)$ after $24 \mathrm{~h}$ incubation. These discrepancies are probably due to a strain effect of the yeasts as shown by Jouany et al. [23] and Newbold et al. [30], and to experimental conditions such as diet and level of feed intake. Not enough results are available in the literature for a precise explanation of the differences in the mode of action of DFMs on plant cell wall degradation. Along with most authors we consider that DFMs 


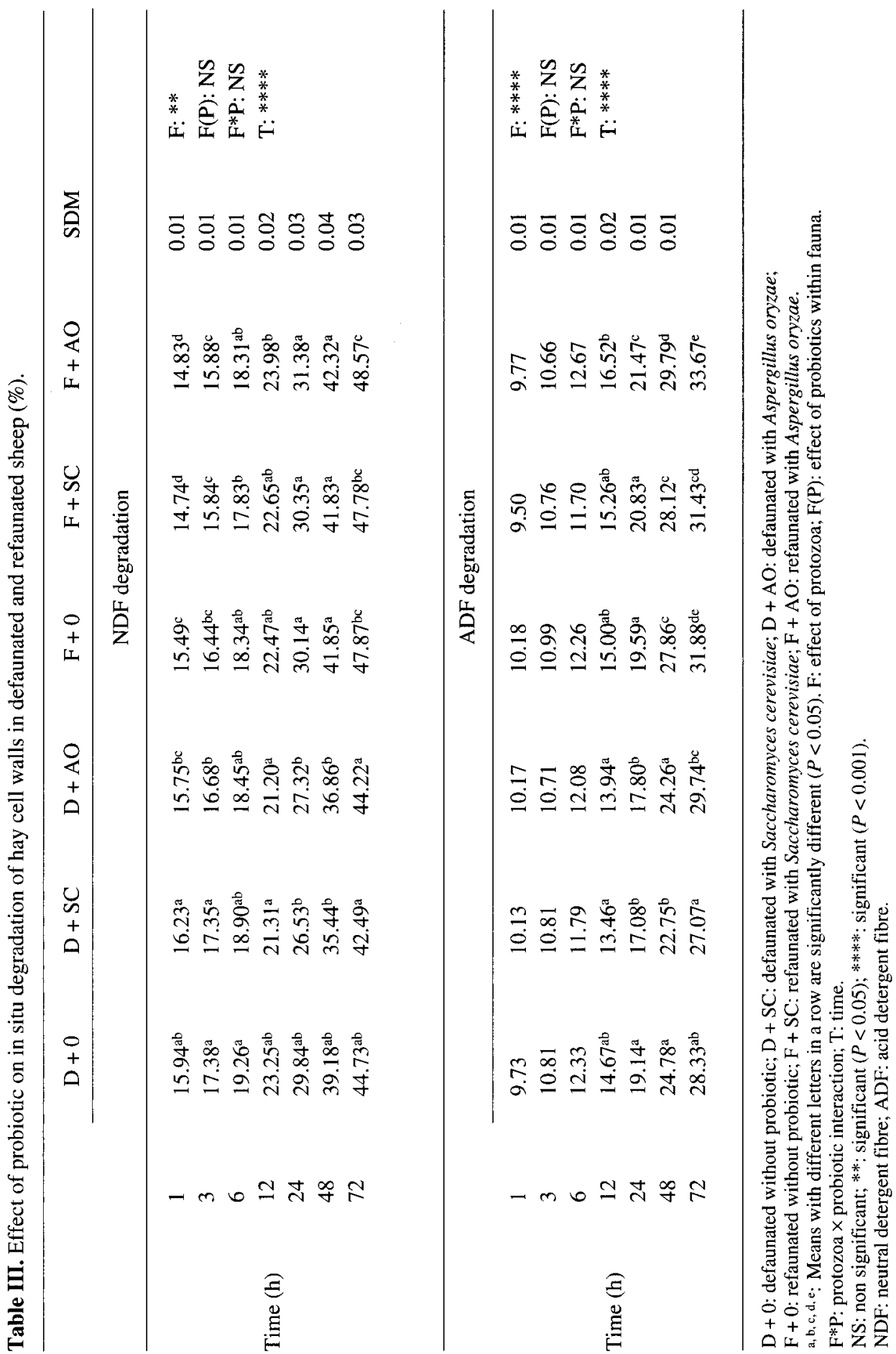


are mainly active at the rumen level, principally when the ruminal ecosystem is disturbed by extreme dietary conditions such as high-starch diets. They have been shown to stabilize the $\mathrm{pH}$ and prevent lactate accumulation in the rumen [26, 28]. Our results confirm that such a stabilizing effect of DFMs is probably involved in the improvement of the in situ ADF degradation beyond the 12 -h residence time in normally faunated rumen [26]. We can also suppose that the presence of large amounts of barley ( $45 \%$ of dietary DM in our experiment), as a cereal rich in rapidly degradable starch, depressed the ruminal fibre degradation [38]. As a consequence, the intestinal digestion of plant cell wall components increased at the expense of the ruminal digestion. According to Archimède et al. [2], who analysed 348 results from 113 recent digestive trials, the intestinal digestion of plant cell wall components increases with the dietary level of concentrate but remains less than $20 \%$ of the total digestible cell walls. Because Newbold et al. [30] showed that survival live cells of SC are found at the ileal level at the same concentration as in the rumen, they considered that probiotics could also act at the intestinal level, essentially at the large intestine level for the digestion of cell walls. In the absence of intestinal cannula on our sheep it was impossible to allow for the partition between the ruminal and intestinal digestion of dietary plant

Table IV. Effect of probiotics on the specific enzymatic activities of LAB and SAB in the rumen of refaunated sheep (nmol substrate/mg protein $/ \mathrm{min})^{*}$.

$$
\mathrm{F}+\mathrm{F} \quad \mathrm{F}+\mathrm{SC} \quad \mathrm{F}+\mathrm{AO} \quad \mathrm{SDM} \quad \mathrm{P}
$$

LAB

Polysaccharide depolymerases

\begin{tabular}{|c|c|c|c|c|c|}
\hline CMCase & $1921^{\mathrm{a}}$ & $2800^{\mathrm{b}}$ & $1677^{a}$ & 329 & ** \\
\hline Xylanase & 12645 & 11697 & 14353 & 1280 & NS \\
\hline coside hydrolases & & & & & \\
\hline$\beta \mathrm{D}$-glucosidase & 48.46 & 41.83 & 40.60 & 4.92 & \\
\hline$\beta$ D-cellobiosidase & 28.58 & 32.47 & 32.12 & 10.89 & NS \\
\hline$\beta D$-xylosidase & $39.24^{\mathrm{a}}$ & $31.58^{\mathrm{b}}$ & $31.32^{\mathrm{b}}$ & 3.04 & $* *$ \\
\hline$\alpha \mathbf{L}$-arabinosidase & 11.43 & 14.87 & 12.20 & 2.62 & NS \\
\hline
\end{tabular}

$\mathrm{SAB}$

Polysaccharide depolymerases

\section{CMCase}

Xylanase

Glycoside hydrolases

$$
\begin{aligned}
& \beta D \text {-glucosidase } \\
& \beta D \text {-cellobiosidase } \\
& \beta D \text {-xylosidase } \\
& \alpha L \text {-arabinosidase }
\end{aligned}
$$

\section{$1776^{\mathrm{a}}$}

14478

\section{$2389^{\mathrm{b}}$}

16720

$53.29^{\mathrm{a}}$

30.28

83.37

18.56

$44.58^{\mathrm{b}}$
30.23
77.87
18.58

$1481^{\mathrm{a}}$

14590

$49.12^{\mathrm{a}}$
26.18
93.92
19.82

188

870

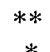

*

$\begin{array}{ll}2.75 & * * \\ 5.24 & \text { NS } \\ 21.06 & \text { NS } \\ 4.35 & \text { NS }\end{array}$

\footnotetext{
* The specific enzymatic activities were not determined during the periods 1 and 2 when animals were defaunated. F + 0: refaunated without probiotic; F + SC: refaunated with Saccharomyces cerevisiae; F + AO: refaunated with Aspergillus oryzae.

a, b: Means with different letters in a raw are significantly different $(P<0.05)$.

P: effect of probiotics; NS: non significant; *: significant $(P<0.10)$; **: significant $(P<0.05)$.

$\mathrm{LAB}=$ liquid-associated bacteria; $\mathrm{SAB}=$ solid-adherent bacteria .
} 
cell walls. However, 1) the close agreement between the positive effect of SC on the digestion of cellulosic and hemicellulosic fractions, and 2) the stimulating effect of $\mathrm{SC}$ on the specific activity of carboxymethycellulase in the rumen $\mathrm{SAB}$ and $\mathrm{LAB}$ and on the xylanase activity in the rumen $\mathrm{SAB}$ (table IV), indicates that $\mathrm{SC}$ acts primarily at the rumen level. Likewise, the absence of any effect of $\mathrm{AO}$ on either the total cell wall digestion or the rumen bacterial enzyme activities supports this hypothesis. The reason why SC decreased the $\beta D$-glucosidase activity in the $S A B$ and both probiotics had a negative effect on the $\beta D$ xylosidase in LAB is difficult to explain.

During the part of our study carried out with the nylon bags, we measured the $\mathrm{pH}$ and determined the protozoa populations inside the bags to compare the values with those obtained in the rumen. Due to a deficit of exchange with the rumen liquid as indicated by Trabalza-Marinucci [40], the $\mathrm{pH}$ values in the bags were 0.1 to 0.6 units lower than the values obtained in the rumen (table $V$ ) and the protozoa were less numerous (table VI). Compared with the rumen, large-size protozoa were three times less numerous in nylon bags, small entodinia decreased by $30 \%$, and holotrichs showed inconsistent modifications. The protozoal population became established after $1 \mathrm{~h}$ in the bags and then remained stable for $72 \mathrm{~h}$. This may indicate that the growth and activity of protozoa were limited by unfavourable environmental conditions inside the bags. If, as we assume, the positive effect of probiotics mainly observed with $\mathrm{SC}$ is also explained by a stimulation of the protozoal population in the rumen as observed in this experiment (table $V I$ ) and in others with SC [3, 34] and AO [12]. This effect did not fully take place in the nylon bags where the concentration of protozoa was less strongly influenced by the two probiotics than in the rumen, which can explain why no effect of probiotics $(P>0.05$ for the global effect of probiotics) appeared in our study on in situ degradation of cell walls (table III). Of course, the stimulation noted on protozoa at the rumen level induces changes in the bacterial population [22]. It is generally considered that protozoa have a detrimental effect on amylolytic bacteria and a positive effect on the bacterial cellulolytic activity in the rumen $[41,48]$. However, the latter cannot be demonstrated inside nylon bags, as reported by Nozière and Michalet-Doreau [31], who showed that the activities of $\mathrm{SAB}$ were lower in bag residues than in rumen digesta. This limitation, added to the reserves expressed on the permeability of the nylon tissue to protozoa and $\mathrm{pH}$ regulation, means the nylon bag technique is not sensitive enough for the testing of feed additives in such dietary conditions.

Addition of probiotics in the rumen of defaunated sheep decreased $(P<0.05)$ the turnover of the ruminal liquid phase (table $V I I)$. Unlike Yoon and Stern [49], who observed a significant decrease $(P>0.05)$ in the liquid turnover following the addition of SC in the rumen of cows, we noted no effect of probiotics on this parameter measured in refaunated sheep. Comparisons made on defaunated and refaunated sheep without probiotics indicated that protozoa decreased the turnover of the ruminal liquid phase. Differences between defaunated and refaunated sheep disappeared when probiotics were given.

In agreement with Caton et al. [6], Westwig et al. [47], Plata et al. [34], there was no significant overall effect of the probiotics on the retention time of solid particles in the digestive tract whatever the model used (table VII). The retention time of digesta in the total digestive tract was significantly lengthened with $\mathrm{AO}$ when the faecal excretion of marker was analysed according to Thielemans et al. [39] and Faichney and Boston [11]. The increase was not significant $(P>0.05)$ when the model of Dhanoa et al. [9] was used. These models gave no information on the retention of digesta in the caecum and colon which could support 


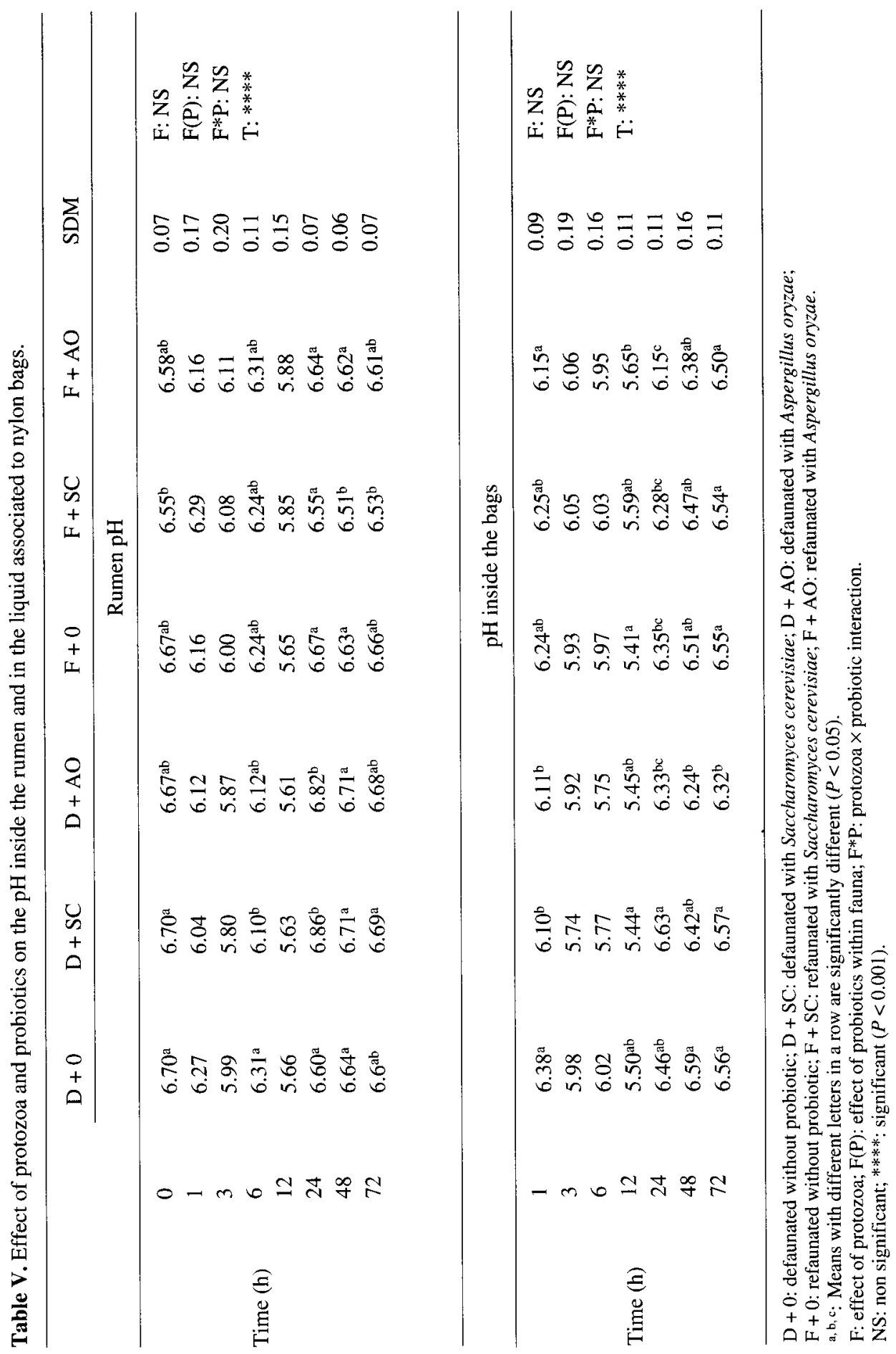


Table VI. Concentration of ciliates $\left(\times 10^{3} \mathrm{~mL}^{-1}\right)$ in the rumen or nylon bag juices.

\begin{tabular}{|c|c|c|c|c|c|c|c|}
\hline \multirow[b]{2}{*}{ Location } & \multicolumn{2}{|c|}{0} & \multicolumn{2}{|c|}{$\mathrm{SC}$} & \multicolumn{2}{|c|}{$\mathrm{AO}$} & \multirow[t]{2}{*}{ SDM } \\
\hline & Rumen & bag & Rumen & bag & Rumen & bag & \\
\hline \multicolumn{8}{|c|}{ Sampling times $(\mathrm{h})$} \\
\hline 1 & $642^{\mathrm{a}}$ & $425^{b}$ & $945 c$ & $665^{a}$ & $1023^{c}$ & $482^{b}$ & 111 \\
\hline 6 & $708^{a}$ & $423^{b}$ & $1110^{c}$ & $506^{\mathrm{b}}$ & $790^{\mathrm{a}}$ & $500^{\mathrm{b}}$ & 124 \\
\hline 12 & $789^{\text {ad }}$ & $483^{b}$ & $1162^{c}$ & $662^{\mathrm{ab}}$ & $908^{c d}$ & $673^{\mathrm{ab}}$ & 120 \\
\hline 24 & $29^{a}$ & $553^{\mathrm{a}}$ & $1122^{b}$ & $614^{a}$ & $920^{b}$ & $610^{\mathrm{a}}$ & 210 \\
\hline 48 & $668^{a}$ & $442^{b}$ & $1092^{\mathrm{c}}$ & $616^{\mathrm{a}}$ & $802^{\mathrm{ac}}$ & $373^{b}$ & 121 \\
\hline 72 & $717^{\mathrm{a}}$ & $446^{\mathrm{b}}$ & $966^{\mathrm{a}}$ & $724^{a}$ & $730^{\mathrm{a}}$ & $463^{b}$ & 137 \\
\hline
\end{tabular}

a. b. c. d: Means with different superscripts in a row are significantly different $(P<0.05)$.

$0=$ without probiotic; SC: with Saccharomyces cerevisiae; AO: with Aspergillus oryzae.

any shift of cell wall digestion from the rumen to the large intestine.

From comparisons between defaunated animals without probiotics and refaunated animals without probiotics, we observed that the presence of protozoa significantly $(P<0.001)$ lengthened the mean retention time in the whole digestive tract by 5 to 10 $h$, whereas no significant effect of protozoa was noted on the retention time of particles in 'compartment 1', which is often identified as the rumen. However, as indicated above, it is impossible to assert from these too imprecise models that digesta are retained longer in the intestinal portion of the digestive tract. Literature data on the effect of protozoa on the transit time of solid particles are conflicting (see [7]). De Smet et al. [8] suggest that protozoa increase the retention of particles in sheep fed diets rich in concentrate but decrease it in sheep fed roughage diets. Our results fit this hypothesis. However, recent experiments carried out by Hegarty et al. [17] and Jouany et al. [24] confirm the wide range of individual animal response to the addition of protozoa in their previously defaunated rumens on the transit time of rumen digesta.

The volume and the ruminal pool of total digesta measured $5 \mathrm{~h}$ after feeding in the defaunated animals were significantly $(P<0.05)$ higher in the presence of AO compared with $\mathrm{SC}$ in defaunated sheep. Differences between the two probiotics disappeared in refaunated sheep (table VIII). AO increased the total pool of liquid only in the defaunated rumen $(P<0.05)$. Neither SC nor AO altered the pools of NDF or ADF in the rumen $(P>0.05)$. Because the animals were given constant amounts of feed, this result means that the rate of cell wall digestion was not changed for the first $5 \mathrm{~h}$ by the addition of SC or AO, which agrees with the results from our kinetic in situ study. The lower specific weight $(P<0.05)$ of the rumen contents in the faunated compared with the defaunated state may be due to the higher production of fermentation gases in the presence of protozoa resulting from larger amounts of fermented OM [20], small gas bubbles being in that case trapped in the rumen digesta and decreasing their specific weight.

\section{CONCLUSION}

$\mathrm{SC}$ without its culture medium stimulated the apparent digestibility of dietary OM in the whole digestive tract of refaunated animals. This result is explained by the positive effect of SC on the digestibility of plant cell 


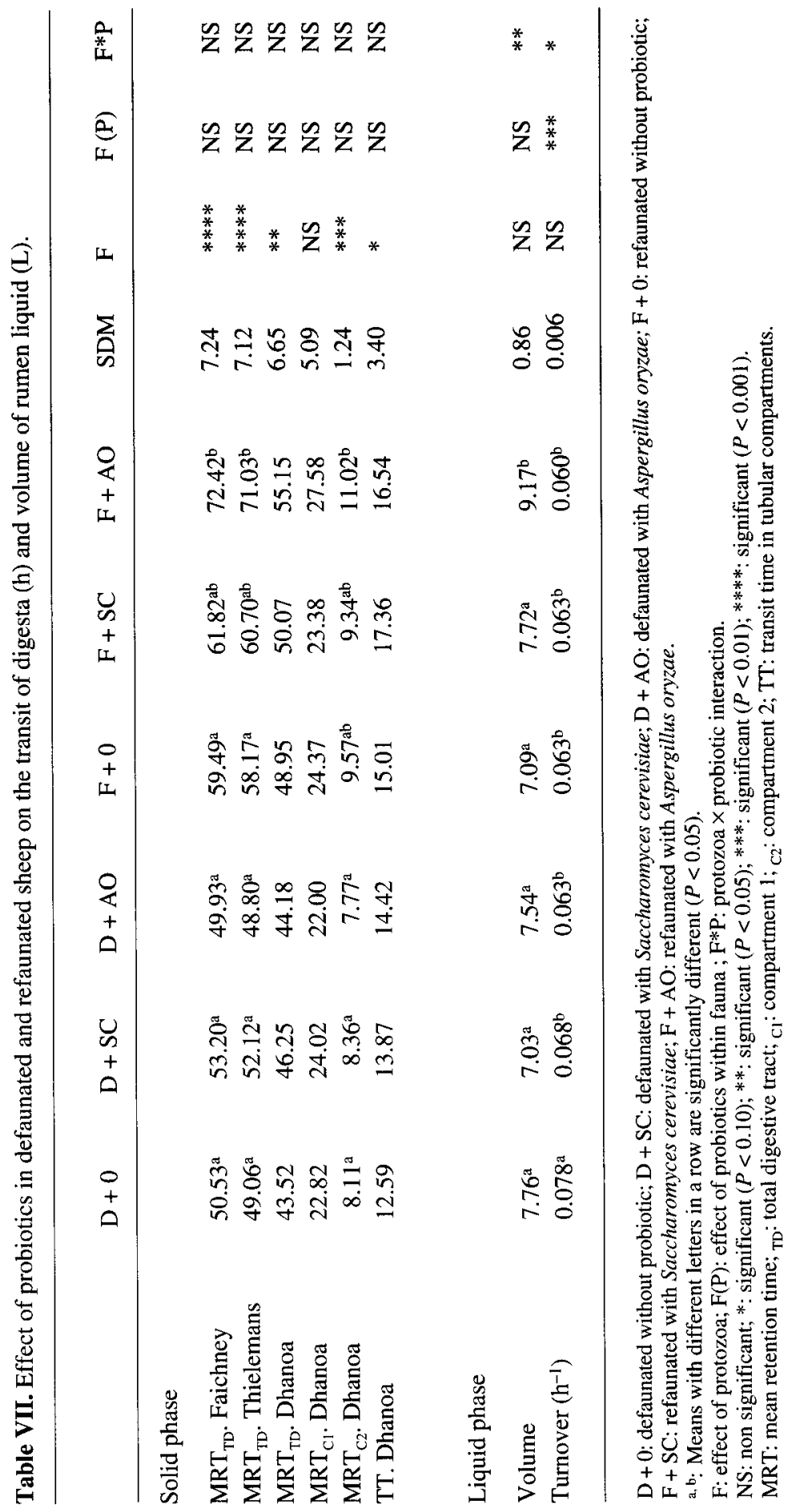




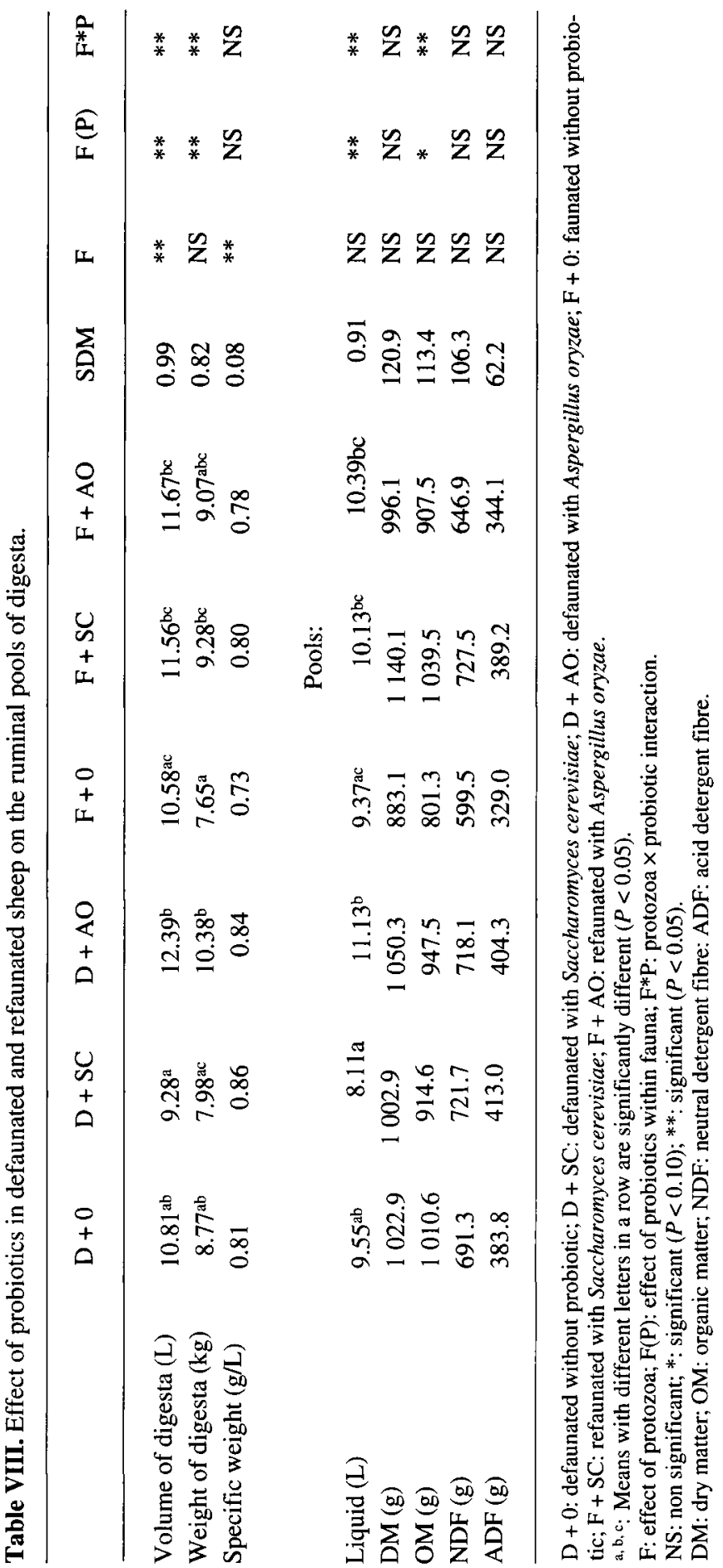


walls. AO had no effect on plant cell wall digestion. SC increased the population of protozoa and stabilized the rumen $\mathrm{pH}$ on diets rich in rapidly fermentable starch, which explains the stimulation of the bacterial specific activity of polysaccharide depolymerases involved in the degradation of hemicellulose and cellulose, thus improving the total cell wall digestion observed in refaunated animals. Protozoa increased the digestive retention time of solid particles which could explain the positive effect of $\mathrm{SC}$ on cell wall digestion in these animals. The results obtained with nylon bags are critically assessed. Probiotics had no effect on the ruminal retention time of solid particles.

\section{ACKNOWLEDGEMENTS}

The authors are indebted to A.G. Williams for his advice and help for the determination of the enzymatic activities of rumen microbes. They thank Sylvie Toillon and M. Fabre for their technical assistance, and J. Lefaivre for surgery.

\section{REFERENCES}

[1] Adams D.C., Galyean M.L., Kiesling H.E., Wallace J.D., Finker M.D., Influence of viable yeast culture, sodium bicarbonate and monensin on liquid dilution rate, rumen fermentation and feedlot performance of growing lambs and digestibility in lambs, J. Anim. Sci., 53 (1981) 780-789.

[2 Archimède H., Sauvant D., Schmidely P., Quantitative review of mineral and total tract digestion of mixed diet organic matter and carbohydrates, Reprod. Nutr. Dev. 37 (1997) 173-189.

[3] Ayala O.J., Gonzales S.S., Herrera R., Barcena R., Mendoza G.D., Effect of a probiotic and a molasses-urea supplement on fiber digestibility of sesame straw, J. Anim. Sci. (1992) 70 (suppl. 1) 307 .

[4] Bernard L., Etude de la dynamique des particules et des liquides dans le réticulo-rumen, chez le mouton recevant une ration de foin de dactyle sous forme hachée et broyée en différentes proportions, Thèse d'Université, Université Blaise Pascal de Clermont-Ferrand II, $n^{\circ}$ d'ordre 466, 1992, $180 \mathrm{pp}$.

[5] Bradford M., A rapid and sensitive method for the quantitation of microgram quantities of protein utilizing the principle of protein-dye brinding, Anal. Biochem. 72 (1996) 248-254.
[6] Caton J.S., Erickson D.O., Carey D.A., Ulmer D.L., Influence of Aspergillus oryzae fermentation extract on forage intake, site of digestion, in situ degradability, and duodenal amino acid flow in steers grazing cool-season pasture, J. Anim. Sci. 71 (1993) 779-787.

[7] Demeyer D.I., Effect of defaunation on rumen fibre digestion and digesta kinetics, in: Nolan J.V., Leng R.A., Demeyer D.I. (Eds.), The Roles of Protozoa and Fungi in Ruminant Digestion, Penambul Books, Armidale, Australia, 1989, pp. 171-179.

[8] De Smet S., Demeyer D.I., Van Nevel C.J., Effect of defaunation and hay: concentrate ratio on fermentation, fiber digestion and passage in the rumen of sheep, Anim. Feed Sci. Technol. 37 (1992) 333-344.

[9] Dhanoa N.S., Siddons R.C., France J., Gale D.L., A multicompartmental model to describe marker excretion patterns in ruminant faeces, Br. J. Nutr. 53 (1985) 663-371.

[10] Edwards I.E., Practical uses of yeast culture in beef production: insight into its mode of action, in: Lyons T.P. (Ed.), Biotechnology in the Feed Industry, Alltech Techn. Publ., Nicholasville, USA, 1991, pp. 51-63.

[11] Faichney G.J., Boston R.C., Interpretation of the faecal excretion patterns of solute and particle markers introduced into the rumen of sheep, J. Agric. Sci. (Cambridge) 101 (1983) 575-581.

[12] Fondevila M., Newbold C.J., Hotten P.M., $\varnothing$ rskov E.R., A note on the effect of Aspergillus oryzae fermentation extract on the rumen fermentation of sheep given straw, Anim. Prod. 51 (1990) 422-425.

[13] Frumholz P.P., Manipulation of the rumen fermentation and its effects on digestive physio$\operatorname{logy}$, Ph.D. dissertation, University of Aberdeen, Scotland, 1991, 240 pp.

[14] Goering H.K., Van Soest P.J., Forage fiber analysis (apparatus, reagents, procedures and some applications), Agric. Handbook $\mathrm{N}^{\circ} 379$, ARSUSDA, Washington, DC, USA, 1970.

[15] Gomez-Alarcon R.A., Effects of Aspergillus oryzae on milk production, feed utilization and rumen fermentation in lactating dairy cows, Ph.D. dissertation, University of Arizona, Tucson, USA, 1988, 102 pp.

[16] Guilford R.J., Olson K.C., Caton J.S., Kirby D.R., Influence of yeast culture supplementation and advancing season on in situ NDF degradability in beef cattle grazing native range in the Northern great plains, J. Anim. Sci. 71 (suppl. 1) (1993) 83.

[17] Hegarty R.S., Nolan I.V., leng R.A., The effects of protozoa and of supplementation with nitrogen and sulfur on digestion and microbial metabolism in the rumen of sheep, Austr. J. Agric. Res. 45 (1994) 1215-1227. 
[18] Hyden S., A turbidimetric method for the determination of higher polyethylene glycols in biological materials, Ann. Lantlrhghs. 22 (1955) 139-145.

[19] Jouany J.P., Contribution à l'étude des protozoaires ciliés du rumen: leur dynamique, leur rôle dans la digestion et leur intérêt pour le ruminant, Thèse de Doctorat, Université Blaise-Pascal de Clermont-Ferrand, Vol. 1 (text), 1978, 195 pp.

[20] Jouany J.P., Defaunation of the rumen, in: Jouany J.P. (Ed.), Rumen Microbial Metabolism and Ruminant Digestion, Inra Editions, Science Update, Versailles, France, 1991, pp. 239-261.

[21] Jouany J.P., Senaud J., Défaunation du rumen de mouton, Ann. Biol. Anim. Bioch. Biophys. 19 (1979) 619-624.

[22] Jouany J.P., Martin C., Effect of protozoa in plant cell wall and starch digestion in the rumen, in: Onodera R. et al. (Eds.), Japan Sci. Soc. Press, Tokyo/S. Karger, Basel, Japan, 1997, pp. 11-24.

[23] Jouany J.P., Fonty G., Lassalas B., Dore J., Gouet Ph., Bertin G., Effect of live yeast cultures on feed degradation in the rumen as assessed by in vitro measurements, $21 \mathrm{st}$ Biennal Conference on Rumen Function, Chicago, Illinois, USA, Abstract 6, 1991.

[24] Jouany J.P., Senaud J., Toillon S., Ben Salah M., Bohatier J., Prensier G., Effect of ruminal inoculation of Isotricha alone or a mixed $\beta$-type fauna in a defaunated rumen on the digestion of a hay-maize diet (70/30) in sheep, Reprod. Nutr. Dev. 35 (1995) 11-25.

[25] Kumar U., Sareen V.K., Singh S., Effect of Saccharomyces cerevisiae yeast culture supplement on ruminal metabolism in buffalo calves given a high concentrate diet, Anim. Prod. 59 (1994) 209-215.

[26] Mathieu F., Jouany J.P., Senaud J., Bohatier J., Bertin G., Mercier M., The effect of Saccharomyces cerevisiae and Aspergillus oryzae on fermentations in the rumen of faunated and defaunated sheep; protozoal and probiotic interactions, Reprod. Nutr. Dev. 36 (1996) 271-287.

[27] Mehrez A.Z., Ørskov E.R., A study of artificial bag technique for determining the digestibility of feed in the rumen, J. Agric. Sci. (Cambridge) 88 (1997) 645-660.

[28] Michalet Doreau B., Morand D., Martin C., Effect of the microbial additive Levucell@ SC on microbial activity in the rumen during the stepwise adaptation of sheep to high concentrate diet, Reprod. Nutr. Dev. 5 (suppl.) (1997) 81-82.

[29] Miranda R.L.A., Mendoza M.G.D., BarcenaGama J.R., Gonzales M.S.S., Ferrara R., Ortega C.M.E., Cobos P.M.A., Effect of Saccharomyces cerevisiae or Aspergillus oryzae cultures and NDF level on parameters of ruminal fermentation, Anim. Feed Sci. Technol. 63 (1996) 289-296.
[30] Newbold C.J., Wallace R.J., Chen X.B., Mc Intosh F.M., Different strains of Saccharomyces cerevisiae differ in their effects on ruminal bacteria numbers in vitro and in sheep, J. Anim. Sci. 73 (1995) 1811-1818.

[31] Noziere P., Michalet Doreau B., Validation of in sacco method: influence of sampling site, nylon bag or rumen contents on fibrolytic activity of solid-associated microorganisms, Anim. Feed Sci. Technol. 57 (1996) 203-210.

[32] Ørskov E.R., Mc Donald I.W., The estimation of protein degradability from incubation measurements weighted according to rate of passage, $\mathrm{J}$. Agric. Sci. (Camb.) 92 (1979) 499-503.

[33] Plata P.F., Gonzales S.S., Mendoza G., Barcena R., Effect of a yeast culture (Saccharomyces cerevisiae) on nutritive value of oat straw based diets fed to Holstein cows, J. Anim. Sci. 71 (suppl. 1) (1993) 307.

[34] Plata P.F., Mendoza M.G.D., Barcena-Gama J.R., Gonzales M.S., Effect of yeast culture (Saccharomyces cerevisiae) on neutral detergent fiber digestion in steers fed oat straw based diets, Anim. Feed Sci. Technol. 49 (1994) 203-210.

[35] Roa M.L., Barcena-Gama J.R., Gonzales M.S., Mendoza G.M., Ortega M.E., Garcia B.C., Effect of fiber source and a yeast culture (Saccharomyces cerevisiae 1026) on digestion and the environment in the rumen of cattle, Anim. Feed Sci. Technol. 64 (1997) 327-336.

[36] SAS Institute Inc., SAS-STAT, Guide for Personal Computers, version 6, Cary, NC, USA, 1987.

[37] Siddons R.C., Paradine J., Beever D.E., Comell P.R., Ytterbium acetate as a particulate phase digestaflow marker, Br. J. Nutr. 54 (1985) 509--519.

[38] Tamminga S., Influence of feeding management on ruminant fiber digestibility, in: Jung H.G., Buxton D., Hatfield R.D., Ralph J. (Eds.), Forage Cell Wall Structure and Digestibility, ASA CSSA SSA, Madison, 1993, pp. 571-602.

[39] Thielemans R.F., Francois E., Bodart C., Thewis A., Mesure du transit gastro-intestinal chez le porc à l'aide de radiolanthanides. Comparaison avec le mouton, Ann. Biol. Anim. Bioch. Biophys. 18 (1978) 237-247.

[40] Trabalza-Marinucci M., Dehority B.A., Loech S.C., in vitro and in vivo studies of factors affecting digestion of feeds in synthetic fiber bags, $\mathrm{J}$. Anim. Sci. 70 (1992) 296-307.

[41] Ushida K., Jouany J.P., Demeyer D.E., Effects of presence or absence of rumen protozoa on the efficiency of utilization of concentrate on fibrous feeds, in: Tsuda T., Sasaki Y., Kawashima R. (Eds.), Physiological Aspects of Digestion and Metabolism in Ruminants, Academic Press, Tokyo, 1991, pp. 625-654. 
[42] Van Horn H.H., Harris B., Taylor M.J., Bachman K.C., Wilcox C.J., By-products feeds for lactating dairy cows: effects of cottonseed hulls, sunflower hulls, corrugated paper, peanut hulls, sugarcane bagasse and whole cottonseed with additives of fat, sodium bicarbonate and Aspergillus oryzae product on milk production, J. Dairy Sci. 67 (1984) 2922-2938.

[43] Varel V.H., Krieikmeir K.K., Influence of feeding Aspergillus oryzae fermentation extract (Amaferm) on in situ fiber degradation, ruminal fermentation, and microbial protein synthesis in non lactating cows fed alfalfa or bromegrass hay, J. Anim. Sci. 72 (1994) 1814-1822.

[44] Varel V.H., Krieikmeir K.K., Response to various amounts of Aspergillus oryzae fermentation extract on ruminal metabolism in cattle, $\mathrm{J}$. Dairy Sci. 77 (1994) 3081-3086.

[45] Wallace R.J., Newbold C.J., Probiotics for ruminants, in: Fuller R. (Ed.), Probiotics, The Scientific Basis, Chapman and Hall, London, 1992, pp. 317-353.
[46] Wallace R.J., Newbold C.J., Mc Intosh F.M., Influence of Saccharomyces cerevisiae NCYC240 and malic acid on bacterial numbers and fiber breakdown in the sheep rumen, $\mathbf{J}$, Anim. Sci. 71 (suppl. 1) (1993) 287.

[47] Westig R.M., Caton J.S., Erickson D.O., Influence of barley and Aspergillus oryzae fermentation extract supplementation on microbial efficiency, duodenal crude protein and amino acid flows, and digesta kinetics in steers fed prairie hay, J. Anim. Sci. 71 (suppl. 1) (1993) 81.

[48] Williams A.G., Withers S.E., Changes in the rumen microbial population and its activities during the refaunation period after the reintroduction of ciliate protozoa into the rumen of defaunated sheep, Can. J. Microbiol. 39 (1993) 61-69.

[49] Yoon I.K., Stern M.D., Effects of Saccharomyces cerevisiae and Aspergillus oryzae cultures on ruminal fermentation in dairy cows, $\mathrm{J}$. Dairy Sci. 79 (1996) 411-417. 